Article

\title{
Wastewater Reclamation Holds a Key for Water Sustainability in Future Urban Development of Phoenix Metropolitan Area
}

\author{
Zhi-Hua Wang ${ }^{1, *(\mathbb{C})}$, Rachel von Gnechten ${ }^{1,2}$, David A. Sampson ${ }^{3}$ and Dave D. White ${ }^{3,4}$ \\ 1 School of Sustainable Engineering and the Built Environment, Arizona State University, Tempe, \\ AZ 85287, USA \\ 2 Department of Civil and Environmental Engineering, University of Illinois at Urbana-Champaign, Urbana, \\ IL 61801, USA \\ 3 Decision Center for a Desert City, Arizona State University, Tempe, AZ 85287, USA \\ 4 School of Community Resources and Development, Arizona State University, Phoenix, AZ 85004, USA \\ * Correspondence: zhwang@asu.edu; Tel.: +1-480-727-2933; Fax: +1-480-965-0557
}

Received: 18 March 2019; Accepted: 24 June 2019; Published: 27 June 2019

check for updates

\begin{abstract}
Global water scarcity has been a growing concern among policy makers, researchers, and the general public. Rapid urbanization with more concentrated populations and emergent patterns of climate change (e.g., soaring temperatures and 19 years of drought) added uncertainty and complexity to the risk of water shortage for the Phoenix Metropolitan Area (PMA). In this study, we used a numerical simulation tool, termed WaterSim 5.0, to assess water sustainability indicators in PMA. Four hypothetical scenarios were evaluated, viz. desert, and green landscaping, as well as urban expansion into desert or agricultural lands, bracketing plausible paths of future development in the study area. Model outputs were evaluated using four sustainability indicators and policy controls: (1) groundwater use, (2) agricultural production, (3) personal water use, and (4) the 100-year adequate water supply metric for new population growth. All four scenarios were examined using both current $(19 \%)$ and complete $(100 \%)$ wastewater reclamation. We found that the rate of wastewater reuse drives a reduction in groundwater dependency in urban growth; urban-agriculture conversion provides a convenient means to enhance water sustainability. In the broader context, sustainable water planning strategies need to take into account other crucial environmental and socio-economic measures such as changes in thermal stress, agricultural production, and outdoor and rural lifestyles.
\end{abstract}

Keywords: arid environment; urban development; WaterSim simulations; water sustainability

\section{Introduction}

As the recent water crisis in Cape Town, South Africa illustrates, water scarcity has emerged as a significant barrier to sustainable urban development by impairing food security and economic prosperity globally [1]. Though a rather extreme case, the averted water crisis in Cape Town could be a harbinger of things to come if global water scarcity is left un-checked. Densely populated areas experience this pressure most severely, when fresh water availability falls below a threshold of, say $\sim 40 \mathrm{~m}^{3} /$ capita/year for domestic household demand (equivalent to 29 gallons per capita per day or gpcd) [2,3]. In addition, water shortage will be exacerbated under projected climatic changes in conjunction with the impact of future population growth [4]. Consequently, a new paradigm is needed for urban planning [5]. 
Water scarcity in cities is rarely a stand-alone issue as it is closely entangled with other urban sustainability challenges, such as urban expansion [6], building energy efficiency [7], water quality [8], and social equity [9]. For example, on top of the potential threat of water scarcity, cities located in arid or semiarid environments often face a "double evil," from the excessive thermal stress in the built environment, known as the urban heat island (UHI) effect [10]. To address the combined challenge of water scarcity and UHI effect, any urban planning strategies need necessarily account for the water-energy nexus, given that the underlying dynamics and transport processes in water and energy cycles are almost always inseparable. The impact, in turn, surfaces in the regional hydroclimate via a cascade of land-atmosphere interactions [11-14]. This is particularly true in the built environment where the complex coupling of heat-water transfer is essential for all realistic urban modeling frameworks $[15,16]$. Thus, questions concerning environmental sustainability in desert cities naturally arise as "how much water does it take to cool a desert city?" [17], or "how to maximize the co-benefit in the water-energy trade-offs?" [18,19].

To address these questions, we selected the Phoenix Metropolitan Area (PMA) in Arizona, USA, as our study area. This area has been among the fastest growing urban areas in the US since 2000 [20]. In PMA, rapid urbanization and the concomitant urban landscape changes have rapidly altered the local hydroclimate in the last decades. Within a relatively short period of 25 years, PMA has experienced decreased precipitation and increased ambient air temperatures; both trends are manifest (Figure 1).

A sustainable water resource with reduced uncertainty in both demand and supply will continue to be a crucial component for residents living, developing, and growing the city. The diversified water portfolio in this region has allowed for its urbanization and agricultural growth of the past [21]. PMA obtains its water from three main sources: the Colorado River via the Central Arizona Project (CAP), the Salt and Verde Rivers via the Salt River Project (SRP), and groundwater aquifers. In particular, treated effluent is also becoming an increasingly more important source for non-potable uses. The treated wastewater is being used in Arizona for a variety of beneficial purposes, including agricultural and landscape irrigation, industrial cooling, and groundwater recharge [22]. Nevertheless, how to best use wastewater sustainably remains a challenging question constrained by trade-offs among wastewater reuse supplies and demands, costs and profits, pollutants reduction, as well as policy restraints [22,23].

In this study, we aim to address the primary research question: "What are the sustainability and socioeconomic implications of water use for different paths of future development of PMA?" Here by socioeconomic implications we mean the implications of water management strategies to the trade-offs of socioeconomic benefits among agricultural yield, building energy demand, and landscape changes subject to urban population growth. Each of the scenarios emphasizes on different aspects of the urban water-energy-population nexus. A systems dynamics model, WaterSim (v5.0) [24,25], is adopted to perform the scenario analysis to estimate water supply and demand. The results of this study will give interesting insight into how water sustainability in a desert city is influenced by different scenarios of population growth, landscape planning strategies, and water management policies. 


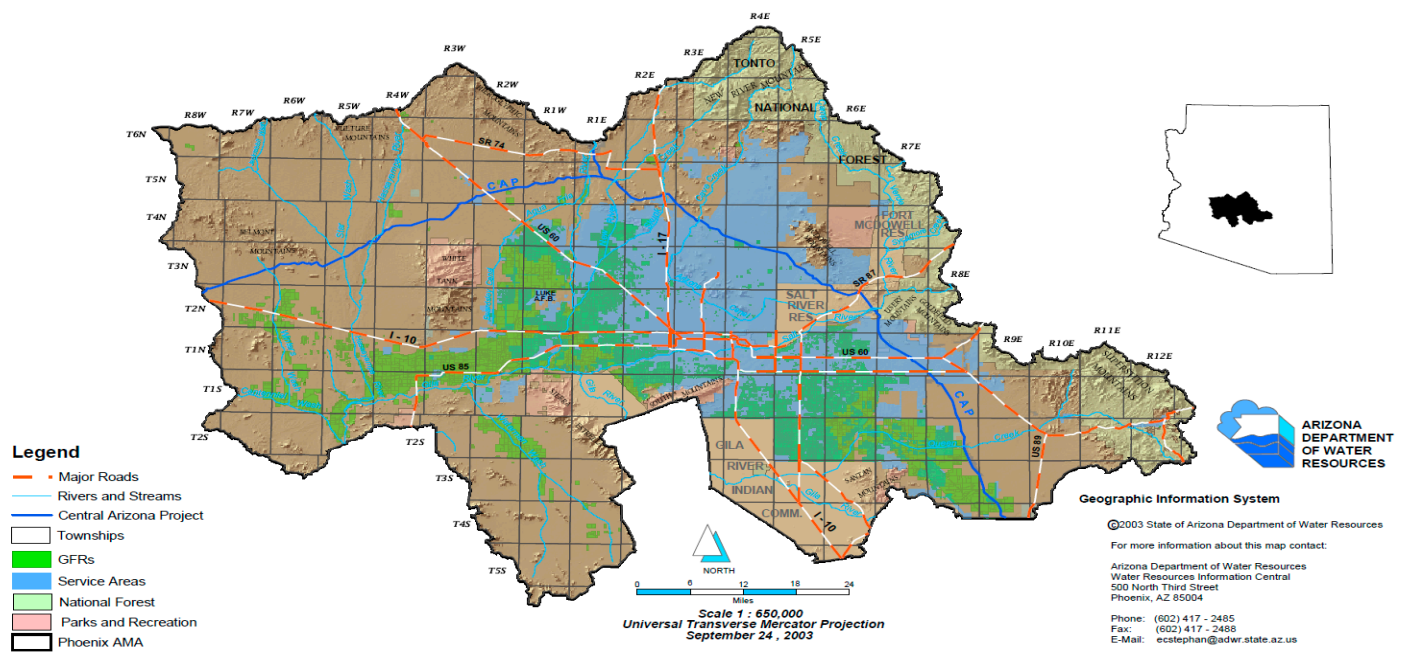

(a)

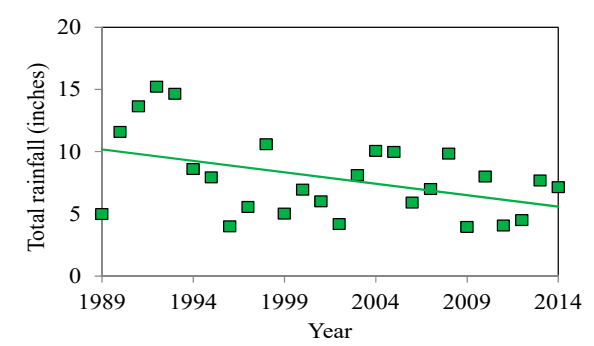

(b)

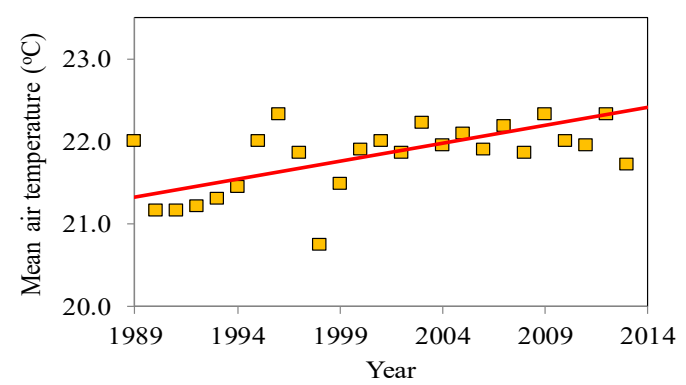

(c)

Figure 1. The study area PMA: (a) map of the Phoenix active management area, and measurements from the local network of Arizona's meteorological stations indicating climatic trends of (b) decreasing annual rainfall, and (c) increasing annual mean air temperature in the last 25 years.

\section{Methodology}

\subsection{Study Area}

The management of water resources in PMA is significantly affected by population growth; nonetheless, the local economy depends on this development [26]. Between 2000 and 2010, the population of PMA grew by 24.2\% [20] and between 2010 and 2015, 100,000 new residents were added annually [27]. Concomitant with population growth, the built area (housing) is projected to increase between 20,000 to 70,000 square kilometers in this area [28,29]. Thus, this anticipated growth and uncertainty due to regional changes is bound to bring water resource challenges.

Facing the double pressure of water scarcity and urban warming, both primarily driven by urban population growth, PMA has adopted a unique portfolio of water management, and landscaping strategies. More specifically, maximizing the reuse of wastewater together with xeriscaping in this 
area offers attractive potential to relieve the stress on overstretched water supplies by replacing other sources of water uses, such as landscape and agricultural irrigation. The status quo of water reuse in central Arizona has been synthesized and reported by Middel [22]; the study also identified potential constraints on wastewater reuse under the current and predicted future economic and regulatory systems.

\subsection{WaterSim}

WaterSim 5.0 is a numerical simulation model developed by the Decision Center for a Desert City (DCDC) at Arizona State University [24,25], and available online at http://wsuied.watersim.org. This water supply and demand management model incorporates current and potential future water policies, in conjunction with controls to emulate climatic and drought-induced effects on riverine runoff, to explore alternate water futures for PMA. The model has been developed with stakeholder input to create a salient and credible education tool for teachers and outreach, as well a tool for researchers, landscape planners, and policy makers [30,31]. The model includes a mass balanced water use network that defines policies that can be used to explore possible, divergent uses of the water supply (and including treated wastewater) for the scenarios of interest (Figure 2). The WaterSim platform includes an online user interface.

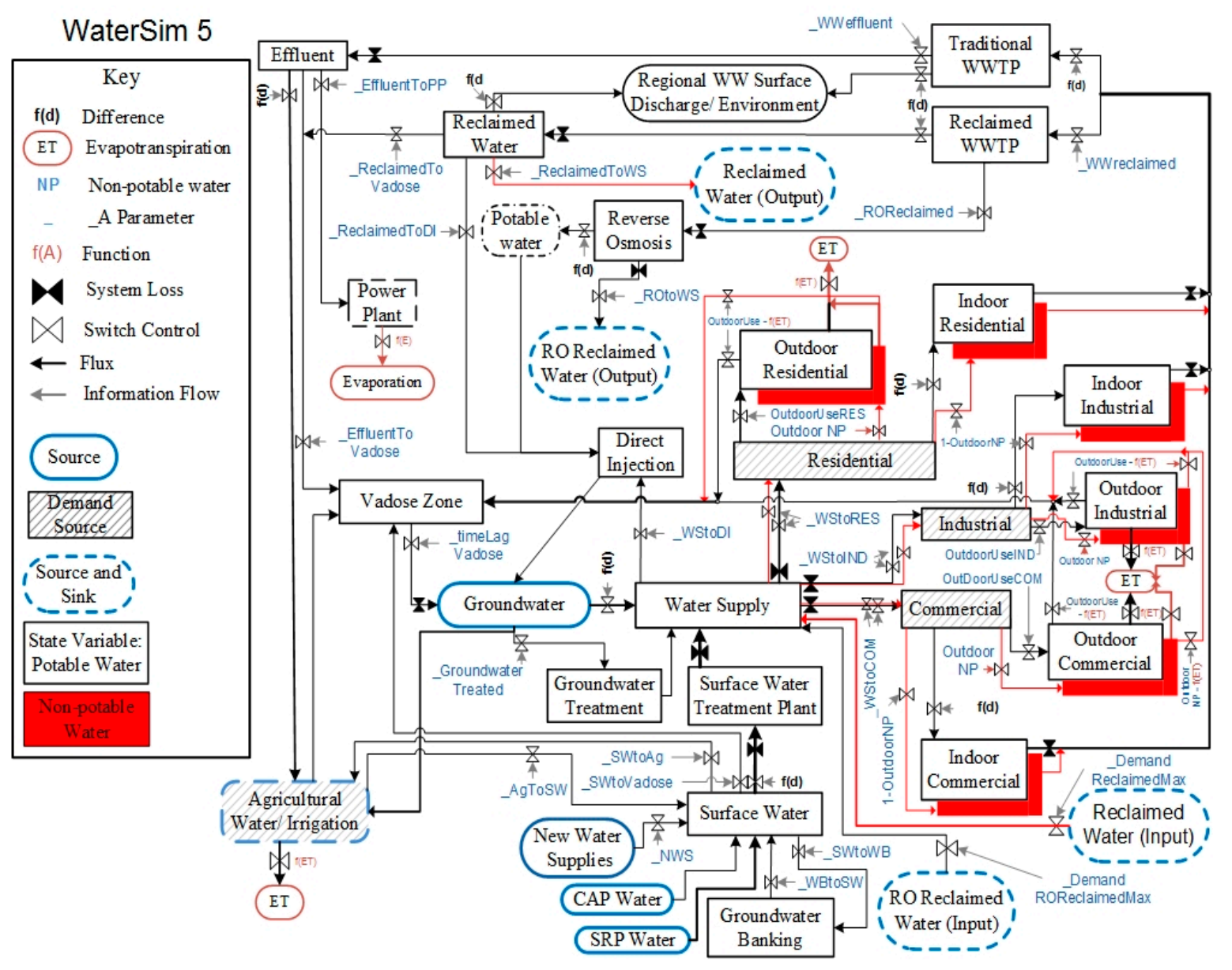

Figure 2. The schematic of the city-model water use network for WaterSim version 5.0.

The WaterSim model simulates the water supply and water demand trajectories for 33 regional water providers in PMA, and utilizes three types of modules to: (1) characterize the uncertainty in water supplies and demand, (2) define urban water infrastructure and the complexity of managing institutions, and (3) integrate a number of policy levers for water supply and demand management 
options [25]. The interface permits users to adjust the: percentage of wastewater reclaimed, percentage of farm water used by cities, environmental flows, the percent change in per capita water use (from the default trajectory), the percent change in population growth (from that projected), and the percent of total water used outdoors.

\subsection{Sustainability Indicators}

For these analyses we focused on four of the five sustainability indicators found in the WaterSim 5.0 user interface (http://phoenix.watersim.org). All values presented in the Sustainability Indicator icons represent regional averages for that indicator found at the end of the simulation cycle (in the year 2050). The groundwater indicator expresses the amount of groundwater used as a percentage of total water use for PMA. The agricultural production indicator reflects the amount of agriculture production in PMA as a percentage of that estimated for 2015 . For example, a value of $81 \%$ in the year 2050 indicates that there was a 19\% reduction in agricultural production as compared to that in 2015. Personal water use, in gallon per capita per day (gpcd), is expressed in the water use indicator. Lastly, the assured water supply indicator depicts the number of years that the region, as a whole, has adequate water to meet the needs of new growth. Specifically, severe groundwater overdraft (i.e., mining of groundwater) led to the establishment of the 1980 Groundwater Management Act [32].

The Arizona Department of Water Resources (ADWR) thus created Active Management Areas (AMAs) in the most populous regions of the state to enable oversight of Arizona's groundwater resources. The Groundwater Management Act granted groundwater rights to cities, towns, and private water providers with the expectation that they would reduce groundwater use to achieve "safe yield" by 2025 [33]. That is, water service provides must reduce reliance on groundwater to the point such that recharge and extraction are roughly in balance [34]. Accordingly, new subdivisions are not allowed to be platted unless developers demonstrate that they have an "assured" 100-year supply (or are located with a water service area that has an assured water supply designation) [32]. Notwithstanding, it is possible that individual cities may have sufficient supplies in 2050 to grow; to verify this supposition, city-specific values for this metric would need to be examined.

\subsection{Scenario Design}

In this study we investigate water sustainability by simulating four plausible future scenarios, including two focusing on a 50 percent increase in the projected population growth for the region, based on the projection by Maricopa association of Governments by 2060, and the other two examining the intriguing interplay of urban water-energy management and their trade-offs: one which deals directly with combating urban heat island (the direct heat mitigation effect is not quantified here), and one concerned with water sustainability alone. The future scenarios are then compared with the baseline scenario to determine the water sustainability of the PMA. The baseline scenario represents our best estimate of the future water supplies and demand assuming no changes in the current policies that each city has established. Water supplies are currently represented of low flow years, using a representative low flow trace (a 30-year slice from the historical data, repeated when the simulation exceeds 45 years) for median river flow estimates from the historical data for each river. Water demand assumes the population growth projected for each water provider by the Maricopa Association of Governments (https://www.azmag.gov/). Our estimates of liters per capita per day for each of 33 municipal water providers for baseline simulations, in conjunction with population, determine the annual water demand. Model parameterization for the baseline scenario required data collection from many sources [25]. Note that the water-energy trade-off suggested here is not directly assessed by WaterSim but inferred from the building energy saving via urban irrigation reported by Yang and Wang $[18,19]$. Specifically, the four scenarios include a green city (GC), a desert city (DC), an expanded city into desert land (ECD), and an expanded city into agricultural land (ECA). These four scenarios were designed to emphasize different aspects of the urban water-energy-population nexus. 
Each of the four scenarios has a single emphatic focus in promoting sustainable development in PMA (Table 1). Primarily, GC and DC serve as contrasting viewpoints on prioritizing planning strategies in mitigating UHI through increased outdoor water use or promoting water sustainability through decreased outdoor water use, whereas ECD and ECA show the influence of population growth and the concomitant urban expansion has on water sustainability. More specifically, the primary objective of the DC scenario is to maximize water saving by encouraging xeric landscaping without concerning the adverse potential effect on UHI. Given an $80 \%$ probability of extended drought between 2050 and 2099 in the area [35], restriction of water only for necessary indoor use becomes a priority by eliminating the outdoor water use (up to $75 \%$ of the total residential water use) for turf, swimming pools, fountains, etc. On the contrary, the GC scenario prioritizes the water use to mitigate UHI as a constant challenge presented in PMA, as well as to reduce heat-related health risks [36]. In addition, the expansion scenarios (ECD and ECA) were created to look at solely the impacts of a high series population growth $[37,38]$, through the trade-offs between urban-agriculture water or urban-desert conversion where the growth occurs. ECD is designed to maintain the status quo agricultural water use where it currently stands, while ECA will entirely overtake agricultural land by the year 2085 . Lastly, each scenario will be analyzed under the polarity of wastewater reuse cases, viz. business as usual (19\% wastewater reclamation) [22], and full reuse (100\%). The input parameters of WaterSim 5.0 for all four scenarios are summarized in Table 2.

Table 1. Design of future urban development scenarios for PMA.

\begin{tabular}{lllll}
\hline \multicolumn{1}{c}{ Scenarios } & Desert City (DC) & Green City (GC) & $\begin{array}{l}\text { Expanded City } \\
\text { into Desert (ECD) }\end{array}$ & $\begin{array}{l}\text { Expanded City } \\
\text { into Agriculture } \\
\text { (ECA) }\end{array}$ \\
\hline $\begin{array}{l}\text { Emphatic } \\
\text { development plan }\end{array}$ & $\begin{array}{l}\text { Maximize water } \\
\text { saving to prepare } \\
\text { for potential } \\
\text { drought }\end{array}$ & $\begin{array}{l}\text { Maximize the } \\
\text { cooling effect by } \\
\text { urban green } \\
\text { infrastructure }\end{array}$ & $\begin{array}{l}\text { Desert-urban } \\
\text { conversion by } \\
\text { preserving } \\
\text { agriculture }\end{array}$ & $\begin{array}{l}\text { Trade-off between } \\
\text { agricultural and } \\
\text { urban water use }\end{array}$ \\
\hline $\begin{array}{l}\text { Population } \\
\text { growth }\end{array}$ & $\begin{array}{l}\text { ADOA-EPS } \\
\text { medium projection }\end{array}$ & $\begin{array}{l}\text { ADOA-EPS } \\
\text { medium projection }\end{array}$ & $\begin{array}{l}\text { ADOA-EPS high } \\
\text { projection }\end{array}$ & $\begin{array}{l}\text { ADOA-EPS high } \\
\text { projection }\end{array}$ \\
\hline Land use change & $\begin{array}{l}\text { Xeric and desert } \\
\text { landscape }\end{array}$ & $\begin{array}{l}\text { Mesic and oasis } \\
\text { landscape }\end{array}$ & $\begin{array}{l}\text { Desert-urban } \\
\text { conversion }\end{array}$ & $\begin{array}{l}\text { Agriculture-urban } \\
\text { conversion }\end{array}$ \\
\hline $\begin{array}{l}\text { Water } \\
\text { sustainability } \\
\text { measure }\end{array}$ & $\begin{array}{l}\text { Eliminating } \\
\text { outdoor water use } \\
\text { for irrigation and } \\
\text { pools }\end{array}$ & $\begin{array}{l}\text { Increasing outdoor } \\
\text { water use for green } \\
\text { spaces }\end{array}$ & $\begin{array}{l}\text { Increasing urban } \\
\text { water use } \\
\text { proportional to } \\
\text { population }\end{array}$ & $\begin{array}{l}\text { Trade-off between } \\
\text { urban and } \\
\text { agricultural water }\end{array}$ \\
\hline
\end{tabular}

PMA = Phoenix Metropolitan Area; ADOA-EPS = Arizona Department of Administration-Office of Employment and Population Statistics; UHI = urban heat island.

Table 2. Input parameter space of future scenarios in WaterSim 5.0.

\begin{tabular}{|c|c|c|c|c|c|c|c|c|}
\hline Scenarios & \multicolumn{2}{|c|}{ DC } & \multicolumn{2}{|c|}{ GC } & \multicolumn{2}{|c|}{ ECD } & \multicolumn{2}{|c|}{ ECA } \\
\hline Farm water used & \multicolumn{2}{|c|}{$30 \%$} & \multicolumn{2}{|c|}{$30 \%$} & \multicolumn{2}{|c|}{$30 \%$} & \multicolumn{2}{|c|}{$100 \%$} \\
\hline Environmental flows & \multicolumn{2}{|c|}{$0 \%$} & \multicolumn{2}{|c|}{$0 \%$} & \multicolumn{2}{|c|}{$0 \%$} & \multicolumn{2}{|c|}{$0 \%$} \\
\hline Per capita water use & \multicolumn{2}{|c|}{$100 \%$} & \multicolumn{2}{|c|}{$100 \%$} & \multicolumn{2}{|c|}{$100 \%$} & \multicolumn{2}{|c|}{$100 \%$} \\
\hline Outdoor water use & \multicolumn{2}{|c|}{$60 \%$} & \multicolumn{2}{|c|}{$120 \%$} & \multicolumn{2}{|c|}{$100 \%$} & \multicolumn{2}{|c|}{$100 \%$} \\
\hline Population growth (relative to that forecasted) & \multicolumn{2}{|c|}{$100 \%$} & \multicolumn{2}{|c|}{$100 \%$} & \multicolumn{2}{|c|}{$150 \%$} & \multicolumn{2}{|c|}{$150 \%$} \\
\hline Wastewater reclaimed & $19 \%$ & $100 \%$ & $19 \%$ & $100 \%$ & $19 \%$ & $100 \%$ & $19 \%$ & $100 \%$ \\
\hline
\end{tabular}




\section{Results and Discussion}

Default simulations from WaterSim 5 demonstrate a slight ( $5 \%)$ increase in the total amount of water used for the metro area from 2015 to 2050, with municipal groundwater pumping, of the six water supply sources, expected to increase the most (Figure 3). This "business as usual" scenario suggests that the region will increase water deliveries from $800 \mathrm{k}$ to $900 \mathrm{k}$ acre-feet per year by 2035 with slight decreases through 2050. At the same time, the four water sustainability indicators suggest: (1) that groundwater use would increase from $10 \%$ to $20 \%$ of the total water portfolio for the region by 2050 , (2) a decrease in the per capita water use to $60 \%$ of that observed in 2015, (3) a decrease in agricultural production of $19 \%$ by 2050 , and (4) that the number of years of assured water supply would drop 10 years from 94 to 84 by the year 2050. Of note, these default simulations, over this time period, suggest that a $5 \%$ increase in total water used would accommodate over 2 million new residents (assuming median surface water flows on the three rivers that supply the metro area and, thus, deliveries).

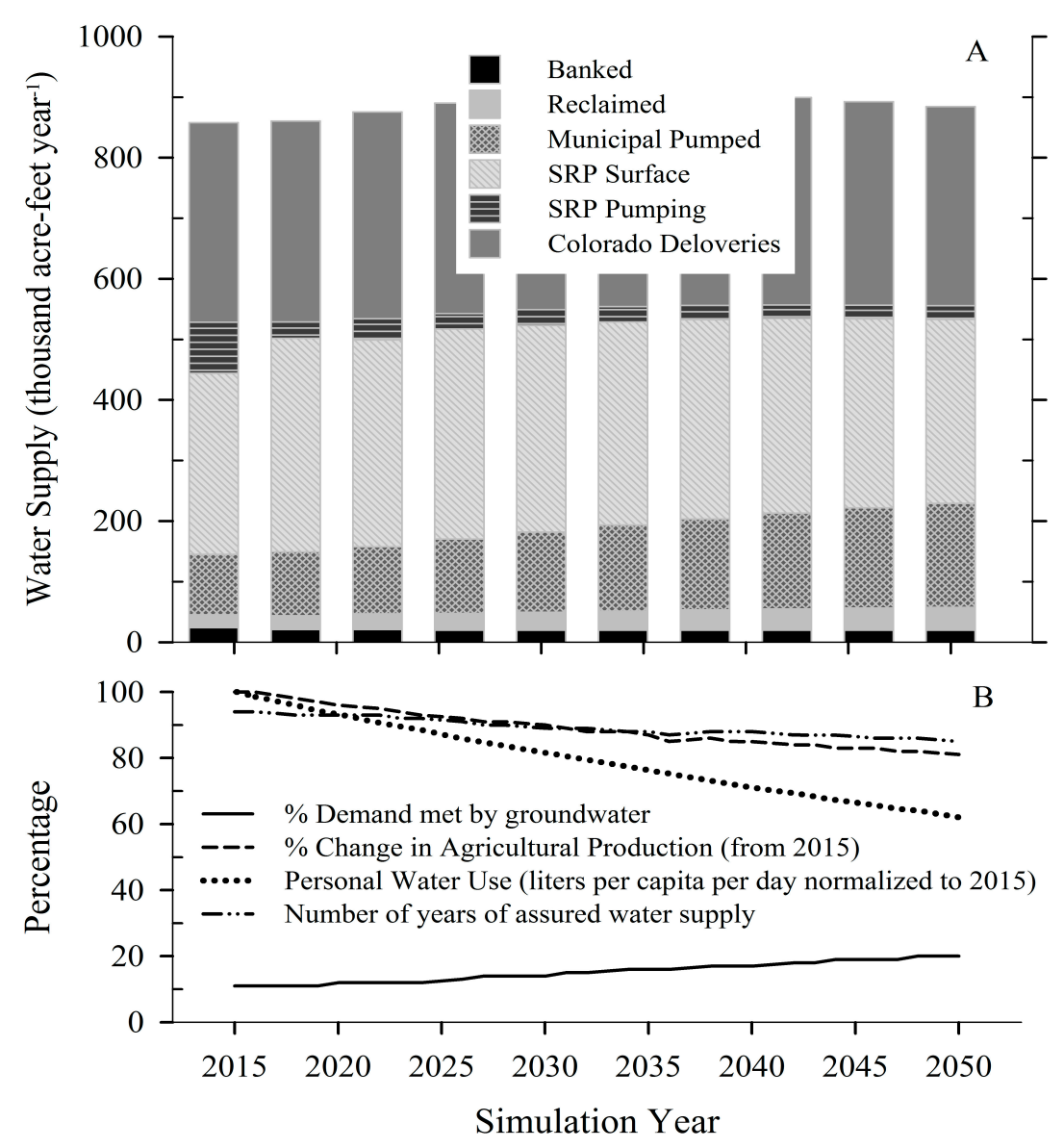

Figure 3. Total water supply for the Phoenix Metropolitan Area by water source (A) and the temporal change in the four sustainability indicators (B) from WaterSim 5.0 for baseline simulations.

\subsection{Impact of Wastewater Reuse}

An increase in the policy control for wastewater reclaimed from 19\% (baseline) to 100\% (maximum) reduced groundwater dependence in all four scenarios is examined. In WaterSim, diverting wastewater from a traditional wastewater treatment plant (TWTP) to a reclaimed wastewater treatment plant (RWTP), without additional policy changes, results in multiple feedbacks that alter the regional water supply mix. First, diverting wastewater from a TWTP to a RWTP reduces effluent that would otherwise be used for agricultural irrigation, cooling towers at the Palo Verde Nuclear Generating Station, and for recharge to the aquifer via vadose percolation (Figure 2). Second, additional reclaimed water (again, with no additional policy changes) can only be used to meet municipal, commercial, and industrial 
outdoor water demand for 11 metro communities that currently have reclaimed wastewater treatment facilities. Accordingly, this water is used for outdoor irrigation of yards, parks and golf courses, replacing potable water use (Figure $4 \mathrm{~A}-\mathrm{D}$ ). Third, for one municipality, increased reclaimed water used increases the amount of reverse osmosis water to be used as direct potable reuse (Figure 2).

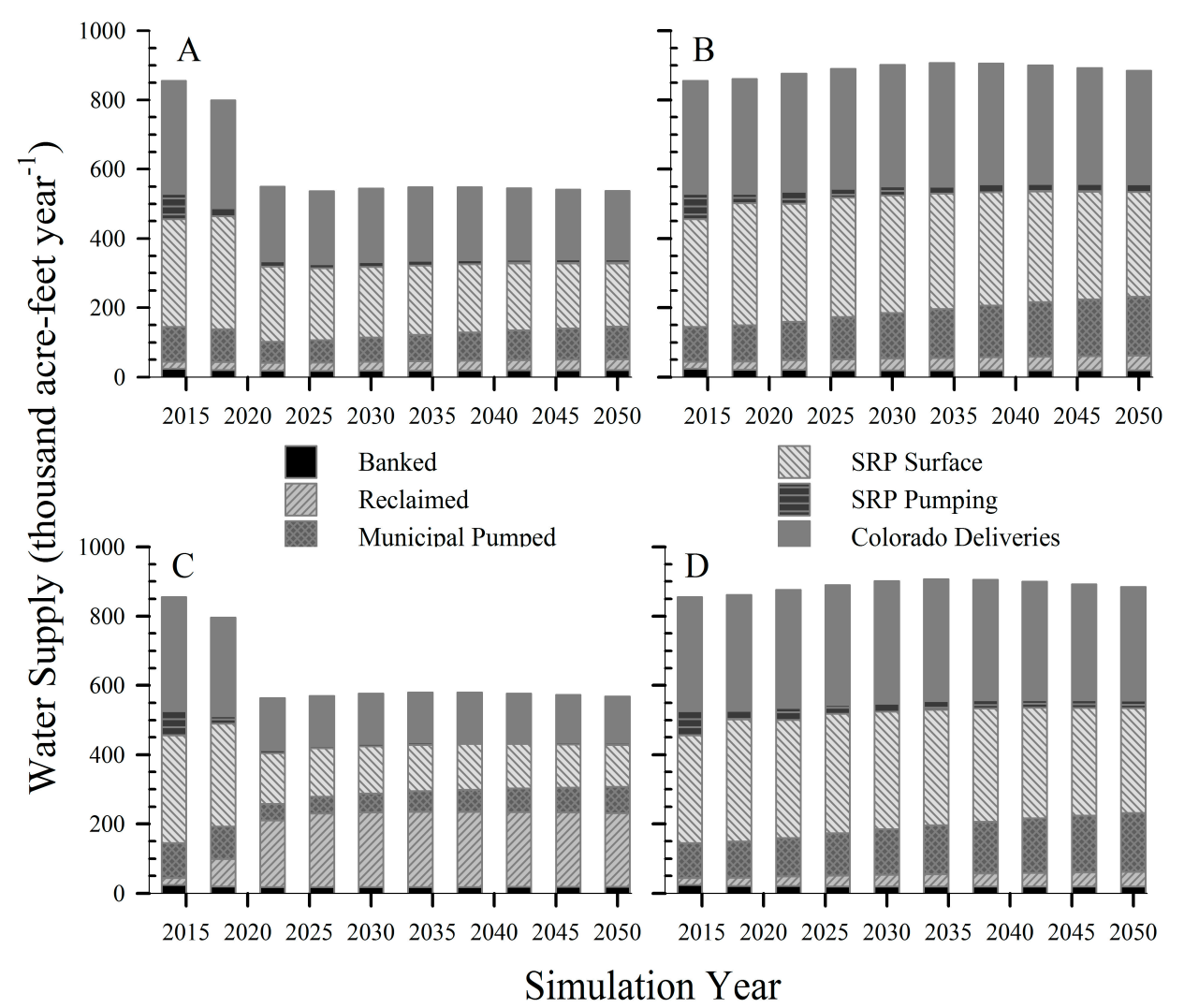

Figure 4. Simulated total water supply, and use for the Phoenix Metropolitan Area by source, for four scenarios: (A) Desert City (DC) with 19\% wastewater reclaimed; (B) a Green City (GC) with 19\% wastewater reclaimed; (C) DC with 100\% wastewater reclaimed; (D) GC with $100 \%$ wastewater reclaimed.

Thus, for 11 water service providers, the additional water from the reclamation plants reduces dependency on surface and groundwater (Figure 4) [25]. In these simulations the decrease in the proportion of groundwater used as a percentage of the total water portfolio for the four scenarios ranged from $4 \%$ to $8 \%$ when $100 \%$ of available wastewater was reclaimed. Note that the WaterSim analysis focuses on 33 of the largest water providers in the PMA. These 33 communities represent $97 \%$ of the total population in the Phoenix Metropolitan Area and contribute to most of the population and the water use in the area. Of course, if more communities added a RWTP to their wastewater treatment infrastructure (a policy within WaterSim) much greater, regional, trends would be observed. The greatest change in groundwater reliance was observed in the Expanded City into Desert Land (ECD) and the Expanded City in Agricultural Lands (ECA) scenarios (8\%).

The Green City (GC) scenario exhibited slightly greater groundwater reliance when compared to the Desert City (DC) simulations (Figure 4 and Table 3), attributed to increased outdoor water use as a percentage of total use by the GC scenario. Outdoor water demand can account for 50 to $70 \%$ or more of total municipal water use [39]. Moreover, decreasing outdoor water use in the DC scenario increased the number of years of adequate groundwater supply; more water was available for indoor water use and, thus, decreased groundwater pumping and the long-term trajectory of groundwater credits over time. Notwithstanding, and of greater significance, both exhibited similar, and what might be considered near sustainable, groundwater use (withdrawals) when reclaimed water use 
was maximized (Table 3); with groundwater use at $14 \%$ of the total water portfolio, these scenarios suggest that the region as a whole would be approaching a safe yield (groundwater pumping equal to groundwater recharge) based on wastewater reclamation by municipalities and farm water use by cities by 2050. While we do not have direct empirical evidence, simulations from WaterSim suggest that natural (along streams and channels) and incidental (from infiltration of agricultural irrigation water, canal leakage, and industrial and municipal outdoor water use) recharge would offset groundwater extraction in the neighborhood of $10 \%$ to $12 \%$ of the total water use profile for the metro area.

Table 3. Summary of simulation results of sustainability indicators.

\begin{tabular}{ccccccccc}
\hline Scenarios & \multicolumn{2}{c}{ DC } & \multicolumn{2}{c}{ GC } & \multicolumn{2}{c}{ ECD } & \multicolumn{2}{c}{ ECA } \\
\hline Groundwater & $18 \%$ & $14 \%$ & $20 \%$ & $14 \%$ & $24 \%$ & $16 \%$ & $24 \%$ & $16 \%$ \\
\hline Agricultural Production & $81 \%$ & $81 \%$ & $81 \%$ & $81 \%$ & $81 \%$ & $81 \%$ & $27 \%$ & $11 \%$ \\
Personal Water Use (gpcd) & 70 & 70 & 117 & 117 & 116 & 116 & 116 & 116 \\
Years of Adequate & 90 & 89 & 85 & 85 & 76 & 81 & 83 & 90 \\
Groundwater Supply & & & & & & & & \\
\hline
\end{tabular}

gpcd $=$ gallons per capita per day.

Increased use of reclaimed water by municipalities has associated tradeoffs. First, it would require much change in water governance and policy dimensions by federal and local agencies to fund the construction of advanced wastewater treatment plants needed to utilize the wastewater stream for municipal, commercial, and industrial water users. Secondly, this change is accompanied by technical and economic constraints. According to [22], wastewater treatment is the largest among all energy users, in conjunction with quality challenges such as high salinity, high total dissolved solids, and pharmaceuticals and personal care products.

\subsection{Impact of Outdoor Water Use}

Limiting outdoor water use can be a potential strategy to increase water sustainability in PMA. In the DC scenario, limiting outdoor water use to $60 \%$ of initial (traditional) use positively impacted the sustainability indicators. This limit lowered the daily personal water use to 70 gpcd (from 117) by 2050 (Table 3) by reducing outdoor water demand. In PMA, landscaping decisions-the type of landscape desired ('xeric' vs. 'mesic' vs. 'oasis') —have, historically, been based on the cooling effect that vegetation provides to make life 'livable' in the hot, arid climate found in PMA. More recent desert-like xeric landscaping (as opposed to mesic turfgrass or an oasis mix of trees and ground cover) has become common, whereby reducing the amount of water needed for outdoor irrigation [40,41], but at a cost. Xeric landscapes (stone, gravel, and native vegetation) increase ambient temperatures whereby increasing the UHI effect of urban environments [41,42]. In contrast, the GC scenario increased outdoor water use (as assumed) for landscape irrigation as a trade-off for increased evapotranspirative cooling by urban green infrastructure [19], but with a greater per capita water use by 2050.

Simulations for the DC scenario suggest that reduced outdoor water use, especially in combination with increased wastewater reclaimed, would increase the number of years of assured water supply over that observed by the GC scenario, but substantially when compared to the ECD or ECA scenarios (Table 3). Reducing outdoor water use in the DC scenario resulted in about a 35\% reduction in total water supplies used (Figure 4 vs. Figure 3). This reduction was transitional, with the full effect not observed until about 2022 (Figure 4). Reductions in total water use was attributed to reduced use across the board but, in this case, much reduced use of Salt River Project surface water (Salt and Verde Rivers of Central-North Arizona) and groundwater was observed (Figure 4 vs. Figure 3). When reclaimed wastewater was included, these differences were even greater.

In a broader context of sustainable urban development, increased water sustainability in the DC scenario (as inferred by the reduced per capita water use and the reduced groundwater dependence) comes at an expense; increased thermal stress would be expected due to reduced evaporative cooling. 
A recent study in PMA reported that a desert city can save up to 80 million $\mathrm{m}^{3}$ (or 21 billion gallons) of outdoor water use from irrigation and evaporation consumption with an approximate increase in daily mean temperature by $0.92{ }^{\circ} \mathrm{C}$ [19]. Even replacing the irrigated landscape by xeriscaping of drought-tolerant plants can lead to the similar effect, albeit with slightly less UHI intensification than a fully desert city [43]. One caveat to this argument is that increased operational costs or even increased water use in some customer classes may occur as an unintended consequence of regional strategies to reduce outdoor water use [44].

\subsection{Impact of Agriculture Water Use}

Of the four scenarios examined, only the ECA scenario addresses agricultural water use. In this scenario, the $70 \%$ increase in the municipal purchase/exchange of agricultural groundwater water credits for potential municipal water use resulted in a dramatic reduction, as would be expected, in agricultural production (Table 3). In this case, agricultural production by 2050 would be about $11 \%$ of that observed in 2015. A monumental reduction in agriculture in the metro area for communities that exchange agricultural lands for urban development greatly enhances their potential sustainability. Shifting water away from agricultural water rights to municipal water rights increases the groundwater pumping credits for a water service provider [25]. Essentially, a water utility may then pump more groundwater on an annual basis than that which was defined in their previously assured designation [33]. In these simulations the ECA scenario added seven to nine years of adequate groundwater supply at the regional scale of the ECD scenario (Table 3). Agriculture uses the lion's share of effluent produced by wastewater treatment plants in PMA, with power generation coming in as a very close second [22].

Historically, agricultural water use in the metro area has accounted for about $47 \%$ of the total water used in the Phoenix AMA [45]. There has been a steady decline in overall agricultural water use over time [22], largely due to increased urbanization that has slowly engulfed the agricultural lands [46,47]. Between 1997 and 2007, $8000 \mathrm{~km}^{2}$ of irrigated agricultural lands were eliminated in the seven Colorado River basin states [17], and this trend is expected to continue. Urbanization of formally agricultural lands, for those lands where groundwater credits can be transferred, results in an uptick in the amount of groundwater that a municipality can pump. With continuous urban population growth, however, local agencies planned to expand the metropolitan area into desert landscape in order to conserve agricultural land and water use [48,49].

This decrease in agricultural production in Arizona would impact the local food production (for livestock and humans) capabilities as well as employment in rural communities. Thus, the water sustainability benefit gained by ECA would be, at least partially, offset by the socioeconomic cost, such as virtual water import of produces. Agriculture has historically acted as a buffer for water supply because it enables flexibility in water use (agricultural lands can be fallowed but households and community cannot simply stop using water) and, because agricultural water is relatively inexpensive, the water credit transfers-especially during times of shortage-would not otherwise exist if agriculture was completely eliminated [43]. The agricultural sector could implement changes to farming practices to reduce water use. Simple changes in improving technologies for irrigation, and planting crops that are less water intensive, could positively influence the water sustainability of agriculture in PMA and other desert cities alike.

\section{Concluding Remarks}

We conducted a systematic evaluation of water sustainability in PMA, an arid desert megalopolis, in the light of four plausible future urban development scenario using different water planning and landscaping strategies. We used a system dynamics model, termed WaterSim, to evaluate four scenarios of water policy and use, viz. desert city, green city, and urban expansion into desert or agriculture land. Salient results indicate that increased use of reclaimed wastewater (wastewater processed in a reclamation water treatment facility) reduced the amount of groundwater used for all plausible scenarios of urban development; each of the scenarios examined had, to greater or lesser extent, positive 
outcomes for improving water sustainability in the PMA. Along these paths, a green city will lead to a cooler environment with added stress to water scarcity, whereas xeriscaping and the conversion of agricultural land into the built environment could help to create a more water sustainable future of the arid city. In two cases observed reductions in groundwater use (as a proportion of total water used) trends towards safe-yield for the region. Reducing outdoor water demand (by, for example, shifting landscapes from mesic or oasis to xeric and/or improving irrigation efficiencies) reduced overall water use for the region, in the neighborhood of about $36 \%$. Nevertheless, a holistic understanding of the socio-economic implications to total environment sustainability, induced by different future paths of urban development, needs to be further evaluated in integrated framework of physical modeling, policies, and urban planning practices.

As modeled with WaterSim, policies that benefit urbanization may have a negative impact on agriculture. Shifting wastewater away from a traditional wastewater treatment plant (effluent) to a reclaimed water treatment plant (reclaimed water-a higher grade of water treatment) to benefit urbanization comes at a cost. Agriculture in the PMA utilizes the dominant share of wastewater produced. Reducing the wastewater stream from effluent to reclaimed water reduced agricultural production. Moreover, increased use of contemporary farm water for urban development (conversion of heretofore agricultural lands for urbanization) also reduced agricultural production, but to a much larger degree. When the proportion of farm water used by cities increased from the 2015 estimate to $100 \%$ of available water, farm production decreased $67 \%$ by 2050 . Nevertheless, if water planners focus on decreasing groundwater dependency, then increasing wastewater reclamation would be an efficient and effective means, provided its technical and economic concerns are to be satisfactorily addressed.

Similarly, if the metropolitan region aims to reduce its overall water use, minimizing outdoor water use and moving towards the concept of DC would be the appropriate action, with repercussions of intensified UHI effects and, consequently, increased energy usage as well as significant changes in landscaping and outdoor lifestyle. Lastly, challenges to water sustainability are even more pressing if the urbanization rate is more rapid than forecasted. The agriculture-urban landscape and water use conversion can sustain a fast growing urban population longer than that of the desert-urban conversion. It is noteworthy that Expanded City into Agricultural Lands (ECA) scenario, with a policy change that dictates $100 \%$ wastewater reuse can sustain the larger projected population similar to the DC scenario with the default projections of population growth (and longer than the more "luxurious" GC scenario). While the option of trading agricultural water for urban users seems attractive, its consequence on reduced agricultural production, loss of water buffers, and eventual economic cost of virtual water import needs to be carefully weighed by policy makers and water planners alike.

Author Contributions: Z.-H.W. conceptualized and supervised the study. R.v.G. and D.A.S. carried out the numerical simulations and data analysis. All authors contributed to the writing of the manuscript.

Funding: This research was funded by the US National Science Foundation (NSF) under Grant No. SES-1462086, DMUU: DCDC III: Transformational Solutions for Urban Water Sustainability Transitions in the Colorado River Basin.

Conflicts of Interest: The authors declare no conflict of interest.

\section{References}

1. Hoekstra, A.Y.; Mekonnen, M.M.; Chapagain, A.K.; Mathews, R.E.; Richter, B.D. Global Monthly Water Scarcity: Blue Water Footprints versus Blue Water Availability. PLoS ONE 2012, 7, e32688. [CrossRef] [PubMed]

2. Savenije, H.H.G. Water scarcity indicators: The deception of numbers. Phys. Chem. Earth 1999, 25, $199-204$. [CrossRef]

3. Damkjaer, S.; Taylor, R. The measurement of water scarcity: Defining a meaningful indicator. Ambio 2017, 46, 513-531. [CrossRef] [PubMed]

4. Schewe, J.; Heinke, J.; Gerten, D.; Haddeland, I.; Arnell, N.W.; Clark, D.B.; Dankers, R.; Eisner, S.; Fekete, B.M.; Colon-Gonzalez, F.J.; et al. Multimodel assessment of water scarcity under climate change. Proc. Natl. Acad. Sci. USA 2014, 111, 3245-3250. [CrossRef] [PubMed] 
5. Gober, P.; Kirkwood, C.W.; Balling, R.C.; Ellis, A.W.; Deitrick, S. Water planning under climatic uncertainty in phoenix: Why we need a new paradigm. Ann. Assoc. Am. Geogr. 2010, 100, 356-372. [CrossRef]

6. Wang, Z.H.; Upreti, R. A scenario analysis of thermal environmental changes induced by urban growth in Colorado River Basin, USA. Landsc. Urban Plan. 2019, 181, 125-138. [CrossRef]

7. Wang, Z.H.; Zhao, X.; Yang, J.; Song, J. Cooling and energy saving potentials of shade trees and urban lawns in a desert city. Appl. Energy 2016, 161, 437-444. [CrossRef]

8. Ward, F.A.; Pulido-Velazquez, M. Efficiency, equity, and sustainability in a water quantity-quality optimization model in the Rio Grande basin. Ecol. Econ. 2008, 66, 23-37. [CrossRef]

9. Bithas, K. The sustainable residential water use: Sustainability, efficiency and social equity. The European experience. Ecol. Econ. 2008, 68, 221-229. [CrossRef]

10. Oke, T.R. The energetic basis of the urban heat island. Q. J. R. Meteorol. Soc. 1982, 108, 1-24. [CrossRef]

11. Song, J.; Wang, Z.H. Interfacing urban land-atmosphere through coupled urban canopy and atmospheric models. Bound. Layer Meteorol. 2015, 154, 427-448. [CrossRef]

12. Song, J.; Wang, Z.H. Diurnal changes in urban boundary layer environment induced by urban greening. Environ. Res. Lett. 2016, 11, 114018. [CrossRef]

13. Song, J.; Wang, Z.H. Evaluating the impact of built environment characteristics on urban boundary layer dynamics using an advanced stochastic approach. Atmos. Chem. Phys. 2016, 16, 6285-6301. [CrossRef]

14. Song, J.; Wang, Z.H.; Wang, C. The regional impact of urban heat mitigation strategies on planetary boundary-layer dynamics over a semi-arid city. J. Geophys. Res. Atmos. 2018, 123, 6410-6422. [CrossRef]

15. Wang, Z.H.; Bou-Zeid, E.; Smith, J.A. A coupled energy transport and hydrological model for urban canopies evaluated using a wireless sensor network. Q. J. R. Meteorol. Soc. 2013, 139, 1643-1657. [CrossRef]

16. Wang, Z.H. A new perspective of urban-rural differences: The impact of soil water advection. Urban Clim. 2014, 10, 19-34. [CrossRef]

17. Gober, P.; Brazel, A.; Quay, R.; Myint, S.; Grossman-Clarke, S.; Miller, A.; Rossi, S. Using watered landscapes to manipulate urban heat island effects: How much water will it take to cool Phoenix? J. Am. Plan. Assoc. 2010, 76, 109-121. [CrossRef]

18. Yang, J.; Wang, Z.H. Optimizing urban irrigation schemes for the trade-off between energy and water consumption. Energy Build. 2015, 107, 335-344. [CrossRef]

19. Yang, J.; Wang, Z.H. Planning for a sustainable desert city: The potential water buffering capacity of urban green infrastructure. Landsc. Urban Plan. 2017, 167, 339-347. [CrossRef]

20. U.S. Census Bureau. 2010 Census of Population and Housing; Technical Documentation DPSF/10-4(RV); Economics and Statistics Administration, U.S. Department of Commerce: Suitland, MD, USA, 2011. Available online: https://www.census.gov/prod/cen2010/doc/dpsf.pdf (accessed on 9 January 2019).

21. Murray, A.T.; Gober, P.; Anselin, L.; Rey, S.J.; Sampson, D.; Padegimas, P.D.; Liu, Y. Spatial optimization models for water supply allocation. Water Resour. Manag. 2012, 26, 2243-2257. [CrossRef]

22. Middel, A.; Quay, R.; White, D.D. Water Reuse in Central Arizona; Decision Center for a Desert City Technical Report 13-01; Arizona State University: Tempe, AZ, USA, 2013.

23. Zhang, W.L.; Wang, C.; Li, Y.; Wang, P.F.; Wang, Q.; Wang, D.W. Seeking Sustainability: Multiobjective Evolutionary Optimization for Urban Wastewater Reuse in China. Environ. Sci. Technol. 2014, 48, 1094-1102. [CrossRef] [PubMed]

24. Sampson, D.A.; Escobar, V.; Tschudi, M.K.; Lant, T.; Gober, P. A provider-based water planning and management model-WaterSim 4.0-For the Phoenix Metropolitan Area. J. Environ. Manag. 2011, 92, 2596-2610. [CrossRef] [PubMed]

25. Sampson, D.A.; Quay, R.; White, D.D. Anticipatory modeling for water supply sustainability in Phoenix, Arizona. Environ. Sci. Policy 2016, 55, 36-46. [CrossRef]

26. Keeler, L.W.; Wiek, A.; White, D.D.; Sampson, D.A. Linking stakeholder survey, scenario analysis, and simulation modeling to explore the long-term impacts of regional water governance regimes. Environ. Sci. Policy 2015, 48, 237-249. [CrossRef]

27. Gober, P.; Sampson, D.A.; Quay, R.; White, D.D.; Chow, W.T.L. Urban adaptation to mega-drought: Anticipatory water modeling, policy, and planning for the urban Southwest. Sustain. Cities Soc. 2016, 27, 497-504. [CrossRef]

28. U.S. EPA. Land-Use Scenarios: National-Scale Housing Density Scenarios Consistent with Climate Change Storylines; U.S. Environmental Protection Agency: Washington, DC, USA, 2019. 
29. Bierwagen, B.G.; Theobald, D.M.; Pyke, C.R.; Choate, A.; Groth, P.; Thomas, J.V.; Morefield, P. National housing and impervious surface scenarios for integrated climate impact assessments. Proc. Natl. Acad. Sci. USA 2010, 107, 20887-20892. [CrossRef] [PubMed]

30. White, D.D.; Corley, E.A.; White, M.S. Water managers' perceptions of the science-policy interface in phoenix, Arizona: Implications for an emerging boundary organization. Soc. Nat. Resour. 2008, 21, 230-243. [CrossRef]

31. White, D.D.; Wutich, A.; Larson, K.L.; Gober, P.; Lant, T.; Senneville, C. Credibility, salience, and legitimacy of boundary objects: Water managers' assessment of a simulation model in an immersive decision theater. Sci. Public Policy 2010, 37, 219-232. [CrossRef]

32. Maguire, R.P. Patching the holes in the bucket: Safe yield and the future of water management in Arizona. Ariz. Law Rev. 2007, 49, 361-383.

33. Gober, P.; White, D.D.; Quay, R.; Sampson, D.A.; Kirkwood, C.W. Socio-hydrology modelling for an uncertain future, with examples from the USA and Canada. Geol. Soc. Lond. Spec. Publ. 2017, 408, 183-199. [CrossRef]

34. ADWR. AZ's Groundwater Management Act of 1980; Arizona Department of Water Resources: Phoenix, AZ, USA, 2016. Available online: https://new.azwater.gov/news/articles/2016-18-11 (accessed on 8 March 2018).

35. Cook, B.I.; Ault, T.R.; Smerdon, J.E. Unprecedented 21st century drought risk in the American Southwest and Central Plains. Sci. Adv. 2015, 1, e1400082. [CrossRef] [PubMed]

36. Patz, J.A.; Campbell-Lendrum, D.; Holloway, T.; Foley, J.A. Impact of regional climate change on human health. Nature 2005, 438, 310-317. [CrossRef] [PubMed]

37. ADOA-EPS. Office of Employment and Population Statistics Maricopa County 2015-2050 Projections; Office of Economic Opportunity, State of Arizona: Phoenix, AZ, USA, 2015. Available online: https://population.az. gov/population-projections (accessed on 8 July 2016).

38. Wang, C.; Wang, Z.H. Projecting population growth as a dynamic measure of regional urban warming. Sustain. Cities Soc. 2017, 32, 357-365. [CrossRef]

39. DeOreo, W.B.; Mayer, P.; Dziegielewski, B.; Kiefer, J. Residential End Uses of Water, Version 2 Executive Report; Water Research Foundation: Denver, CO, USA, 2016; p. 15.

40. Larson, K.L.; White, D.D.; Gober, P.; Wutich, A. Decision-Making under Uncertainty for Water Sustainability and Urban Climate Change Adaptation. Sustainability 2015, 7, 14761-14784. [CrossRef]

41. Song, J.; Wang, Z.H. Impacts of mesic and xeric urban vegetation on outdoor thermal comfort and microclimate in Phoenix, AZ. Build. Environ. 2015, 94, 558-568. [CrossRef]

42. Middel, A.; Hab, K.; Brazel, A.J.; Martin, C.A.; Guhathakurta, S. Impact of urban form and design on mid-afternoon microclimate in Phoenix Local Climate Zones. Landsc. Urban Plan. 2014, 122, 16-28. [CrossRef]

43. Larson, K.L.; Polsky, C.; Gober, P.; Chang, H.; Shandas, V. Vulnerability of water systems to the effects of climate change and urbanization: A comparison of Phoenix, Arizona and Portland, Oregon (USA). Environ. Manag. 2013, 52, 179-195. [CrossRef]

44. Quay, R.; Hester, C.; Larson, K.L.; White, D.D. Urban Landscape Water Use Research Evaluation; Water Research Foundation: Denver, CO, USA, 2018; p. 115.

45. ADWR. Arizona Water Atlas, Volume 8: Active Management Area Planning Area; Arizona Department of Water Resources: Phoenix, AZ, USA, 2010; p. 456.

46. Gammage, G.J.; Stigler, M.; Clark-Johnson, S.; Daugherty, D.; Hart, W. Watering the Sun Corridor: Managing Choices in Arizona's Megapolitan Area; Morrison Institute for Public Policy, Arizona State University: Tempe, AZ, USA, 2011; p. 40.

47. Gober, P.; Kirkwood, C.W. Vulnerability assessment of climate-induced water shortage in Phoenix. Proc. Natl. Acad. Sci. USA 2010, 107, 21295-21299. [CrossRef]

48. Auch, R.; Taylor, J.; Acevedo, W. Urban Growth in American Cities: Glimpses of U.S. Urbanization; U.S. Department of the Interior and U.S. Geological Survey: Reston, VA, USA, 2004. Available online: https: //pubs.usgs.gov/circ/2004/circ1252/ (accessed on 8 January 2019).

49. Bolin, B.; Seetharam, M.; Pompeii, B. Water resources, climate change, and urban vulnerability: A case study of Phoenix, Arizona. Local Environ. 2010, 15, 261-279. [CrossRef]

(C) 2019 by the authors. Licensee MDPI, Basel, Switzerland. This article is an open access article distributed under the terms and conditions of the Creative Commons Attribution (CC BY) license (http://creativecommons.org/licenses/by/4.0/). 